\title{
Consultation-liaison psychiatry and psychosomatic medicine, A University Hospital Center Sestre milosrdnice model
}

\author{
Dalibor Karlović1, ${ }^{1,}$ Andrea Gurović ${ }^{1}$, Vjekoslav Peit $\left.\right|^{1,2}$, \\ Iva Ivančić Ravlić ${ }^{1}$, Danijel Crnković ${ }^{1}$, Branka Vidrih ${ }^{1,2}$ \\ ${ }^{1}$ Department of Psychiatry, Sestre milosrdnice University Hospital Center, Zagreb, Croatia, \\ ${ }^{2}$ Catholic University of Croatia, Zagreb, Croatia
}

\begin{abstract}
The aim of this paper is to demonstrate an active participation of the Department of ConsultationLiaison Psychiatry and Psychosomatic Medicine as the first and currently the only formally founded department of that kind in Croatia. Consultation-liasion psychiytry in Sestre milosrdnice has been present for decades, from the time when psychiatry department was founded at the hospital. Nevertheless, Department as an organizational unit has been active for the last six years. It is important to emphasize the cooperation and consultation between the specialists in "somatic" medicine and psychiatrists as well as to point out a psychosomatic aspect in physical illness. Moreover, the importance of psychiatrist's role in discovering, providing diagnosis and treating "somatic"patients with psychiatric complications must be placed in the focus, and the rest of the medical team needs to be aware that each patient has its own biological, psychological and social dimension which requires a holistic, bio-psycho-social approach regardless of the patient's physical or mental disorder.
\end{abstract}

Keywords: consultation - liaison psychiatry, psychosomatic medicine, hospital, organization of psychiatric service, psychiatric disorders in "somatic" patients

Copyright (C) 2018 KBCSM, Zagreb

e-mail: alcoholism.kbcsm@gmail.com•www.http://apr.kbcsm.hr

\section{Introduction}

Consultation-liasion psychiytry (also called liaison psychiatry) begins its development between two world wars when psychiatric departments and psychiatrists were merged with general hospitals. Not long ago, psychi-

Correspondence to: Dalibor Karlović

Department of Psychiatry, Sestre milosrdnice University Hospital

Center,Vinogradska cesta 29., 10000 Zagreb

E-mail:dalibor.karlovic@gmail.com atric patients were mostly treated in psychiatric hospitals separated from non-psychiatric patients hence the separation from other doctors, specialists in different medical fields. In situations when psychiatric patients would suffer from physical illness during hospitalization in non-psychiatric general hospitals departments, they were left without necessary medical treatment [1].

As the name suggests, the area of expertise includes consultation and collaboration 
between non psychiatrist doctors and psychiatrists as well as recognizing psychosomatic in physical illness [2]. Apart from psychiatrist's consultation in providing diagnosis and treating psychiatric patients, who are situated in general hospital , a consultation - liaison psychiatrist is involved in discovering, providing diagnosis and treating primarily physical patients with psychiatric and psychological complications, reactions to physical illness, physical manifestations of mental disorders and psychosomatic disorders [3]. According to this model the primary role of a psychiatrist is to provide greater insight into holistic approach in diagnostics and treatment of non psychiatric patients, therefore it supports bio-psycho-social approach. Therefore, apart from consultation role, this model suggests that a psychiatrist is part of medical team and that one part of working hours he spends in non-psychiatric medicine departments collaborating closely with other medical staff. Consultation-liaison psychiatrists should look at each patient's psychiatric and psychological context of disorder and to the rest of the medical team they emphasize that a patient is a person with biological, psychological and social dimension. The importance of implementation of a consultation- liaison psychiatrist model in general hospitals is also seen in the fact that $5 \%$ of hospital treated patients in non-psychiatric medicine departments had psychiatric consultation and around $30 \%$ of patients in general hospitals have some form of a psychiatric disorder. Out of these 30\%, $10 \%$ have acute psychoorganic disorder, around $10 \%$ have mood disorder and $5 \%$ adjustment disorder [4,2].

Thus, the result is a logical connection between consultation-liaison psychiatry and psychosomatic medicine. In fact, while consultation-liaison psychiatry covers "practical work" of a psychiatrist, psychosomatic medicine believes in the intertwining of mental and physical, or in other words psychosomatic medicine connects psychical and mental and monitors their mutual relation. On the other side a consultation-liaison psychiatrist most frequently encounters psychosomatic disorders $[5,6]$.

\section{History of consultation-liaison psychiatry and psychosomatic medicine at University Hospital Center Sestre milosrdnice}

It is important to mention that the founder of a psychiatric unit of University Hospital Center Sestre milosrdnice was Professor Josip Glaser, MD, PhD, a scholar of famous Eugen Bleuler, the first in our area to write in 1946 a scientific paper about the importance of psychiatric service in a general hospital [7]. Since the early beginnings of a psychiatric department at Sestre milosrdnice, there has been an interest and the awareness of the importance of the presence of psychiatrists among non-psychiatry doctors. Moreover, in the field of psychiatric protection University Hospital Center Sestre milosrdnice is one of the pioneers in this area. In addition, it is important to mention that even before the formal foundation of the department of psychiatry, the hospital treated psychiatric patients from the very beginnings of the $19^{\text {th }}$ century. During that period psychiatric patients were treated in internal medicine department and their psychiatric complications, which resulted from their physical illness, have been a constant interest for doctors [8]. In 1897 in Sestre milosrdnice the first scientific paper was written on the topic which continues to be in the focus of todays' consultation-liaison psychiatrists, and is related to psychotic clini- 
cal pictures which resulted from head trauma. One of the founders of Medical School in Zagreb, Professor Miroslav Čačković was also involved in writing the paper [9].

Taking into account that the Department of Psychiatry of University Hospital Sestre milosrdnice is the oldest department of psychiatry in general hospitals in the Republic of Croatia, present since 1939, it is quite understandable that psychiatrists have been involved in consultation since the early beginnings. In fact, as it was mentioned in the introduction, the hospital initiated and emphasized the importance of psychiatric service in general hospitals, which was published in Liječnički vjesnik in 1946 [10]. For the last couple of decades, a more recent consultation-liaison model was set up as part of semi clinic-consultation service of the Department of Psychiatry through consultation follow ups. The significance of consultation-liaison psychiatrist service of the Department of Psychiatry of Sestre milosrdnice is visible in the name itself which contains the word consultation. Nevertheless, even in this period, consultation- liaison work was organized according to the principles of consultationliaison psychiatry in a way that some psychiatrists were in charge of psychiatric consultations in specific departments. In fact, numerous works written by the employees of the Department of Psychiatry from the field of consultation- liaison psychiatry and psychosomatic medicine speak of the fact that psychiatrists from the Department were systematically and seriously engaged with problems of consultation- liaison psychiatry and psychosomatic medicine. During the nineties the work of the consultation- liaison psychiatrists has become more intensified when the psychiatrists employed at the Department of Psychiatry became team members for diag- nostics and treatment as liaison psychiatrists (not just consultation psychiatrists). Onward, for the last fifteen years, a liaison psychiatrist spends part of working hours at the Department of Oncology providing psychooncological support with oncological patients. The same Department organized special psychosocial counseling for oncological patients and their families. Apart from that, for the last six years we have consultation-liaison and psychosomatic, psychodermatology at the Department of Skin and Sexually Transmitted Diseases as well as liaison approach for the treatment of anorexia and bulimia at the Department of Pediatrics, liaison approach at the Department of Gynecology and Obstetrics for treating mental disorders related to pregnancy and postpartum period. At the Department of Internal Medicine since the nineties there has been a liaison approach in the treatment of suicidal patients who are hospitalized in intensive internal care after suicide attempt. There has also been a close cooperation with the School of dental medicine, Oral Medicine Institute, where through liaison approach, patients with psychostomatological disorders are diagnosed and treated with special emphasis on psychosomatic aspect. Finally, we would like to stress that since 2002 at the Department of Psychiatry there has been an official Department of Consultation-liaison psychiatry and psychosomatic medicine which deals with prevention, diagnostics and therapy in the field of consultation-liaison psychiatry and psychosomatic medicine. This Department is the first and only Department which was formally organized and set up in a hospital in the Republic of Croatia. Seeing that in Croatia there are 23 general hospitals with psychiatric services and 6 general hospitals without stationary psychiatric unit, some of them even without 
a psychiatric dispensary, hence the need for establishing the head institution which would encourage the setting up of consultation- liaison service in general hospitals, give them guidelines for everyday work in consultationliaison activities, organize education of medical employees in the field of consultation-liaison psychiatry and psychosomatic medicine and implement and organize research in the field of consultation-liaison psychiatry and psychosomatic medicine.

\section{Consultation-liaison psychiatry and psychosomatic medicine in nursing}

PCLN (psychiatric consultation-liaison nurse) is an international name for a nurse who works in the Department of Consultation-liaison psychiatry and psychosomatic medicine. Consultation- liaison psychiatry in nursing is present in many countries, especially the USA, Australia, New Zeland, Great Britain, in most European countries, and not long ago it has become active in Croatia within Sestre milosrdnice University Hospital center [11]. In fact, nurses' role in consultation-liaison psychiatry has been present for over 40 years, but not until the year 1987 when a small PCLN group gathered at their first conference in the USA and founded special interest group with the support of ANA (American nurses association) and published standards for practical work of nurses in consultationliaison psychiatry as well as work principles in 1990. The same group of nurses formed an international PCLN society in 1996 and PCLN association for education and research in 1999 [12]. Nurses who work at the Department of consultation-liaison psychiatry have to receive proper education concerning mental disorders as well as physical illnesses, their etiological mutual connection, which will re- sult in a better nursing care for each patient. Nurses in consultation-liaison psychiatry also need to have necessary experience and proper education in the work in psychiatric wards as well as additional education through various lectures and seminars in order for them to be able to recognize the etiology of emotional response to physical illness [13]. PCLN nurses are required to perform various assignments from the field patients' health care, establish nurses' competences in consultation-liaison psychiatry, define nursing diagnosis, that is health care problem, determine patients' needs, plan interventions within the field of consultation-liaison psychiatry, perform evaluation and assess successfulness of the carried out tasks and which relate to patients with psychosomatic and psychosocial problems [14]. We mustn't forget to include patients' families who are also involved in patients' health condition [15]. Each PCLN nurse after finishing education has to be able to understand and recognize the influence of physical pain on emotional and interpersonal patient's functioning [13]. Psychosocial aspects of nursing care are combined with biophysical care where it is necessary to promote health within consultation-liaison psychiatry. PCLN nurses possess strong emotional competences (self-awareness, self-confidence, empathy, social skills), ability to set up good quality relations, ability of fast inclusion and system adjustment, flexibility, should be equipped for assistance, evaluation, education and complete psychosocial patient's care. Furthermore, it is necessary to exchange experience, knowledge and skills with other PCLN nurses. Each PCLN nurse should be involved in various scientific studies from the field of consultation-liaison psychiatry and psychosomatic medicine. Results and achievements of nurses in consul- 
tation-liaison psychiatry have multistructural concept which includes clinical, physiological, physical, psychological, psychosocial and evaluation dimensions [15,11].

At the Department of Consultation-liaison psychiatry and psychosomatic medicine of University Hospital Sestre milosrdnice in Zagreb nurses are involved in the work of consultation-liaison psychiatry and psychosomatic medicine. This approach is relatively new, although we aspire to implement world standards, and have actively started applying this approach at the Department of Psychiatry of University hospital Sestre milosrdnice in Zagreb.

\section{Work organization at the Department of Consultation-liaison psychiatry and psychosomatic medicine of University Hospital Center Sestre milosrdnice}

Consultation-liaison psychiatry and psychosomatic medicine at the University hospital center Sestre milosrdnice is the first formally founded department in Croatia and it is based on modified Italian model. The entire process of psychiatric consultation is computer based in a way that the Department includes register and data base of consultation-liaison services at the university hospital Sestre milosrdnice. In fact, the data base represents the foundation for implementation of various epidemiological studies and monitoring the needs of certain Clinics for psychiatric consultation. Consequently, the psychopathology prevalence in certain groups of physical patients will be explored. University hospital Sestre milosrdnice has 923 beds, excluding psychiatry, and it consists of 15 Departments. The departments are as follows: Department of Internal Medicine, Department of Surgery, Department of Neurology,
Department of Neurosurgery, Department of Ophthalmology, Department for Skin and Sexually Transmitted Diseases, Department of Gynecology and Obstetrics, Department of Anesthesiology, Department of Urology, Department of Physical Medicine and Rehabilitation, Department of Rheumatology, Department of Otorhinolaryngology, Head and Neck Surgery, Department of Pediatrics, Department of Oncology and Nuclear Medicine, Department of Psychiatry.

The work of consultation-liaison psychiatry is implemented in all previously mentioned Departments and this clearly shows its importance and necessity in the work process within all Departments in Sestre milosrdnice. Accordingly, patients are adequately taken care of through holistic approach of Consultation-liaison psychiatry which connects and heals mental as well as "physical" condition in order to meet all patients' needs. Common goal of Consultation-liaison psychiatry and psychosomatic medicine and "somatic" medicine is to achieve the best possible health condition of a patient, accordingly taking care of all their needs. Annually, university hospital Sestre milosrdnice has around 1100 psychiatric consultations, with an average of 5 consultations per day, which accounts for $3 \%$ of hospital-treated patients.

Consultation-liaison psychiatry and psychosomatic medicine are actively implemented in all clinical departments in Sestre milosrdnice. Intensive care units (internal and surgical intensive care units, coronary units, gastrointestinal intervention, internal medicine unit), following the Departments of Oncology and Hematology where psychooncological counseling for patients and their families is of the utmost importance, gynecology (to provide help for female addicts after birth, to women with postpartum 
disorders and psychiatric female patients who are hospitalized due to risky pregnancies). In addition, it is actively implemented in surgery, especially with stomach operations with obese persons, (aesthetic procedures and plastic surgeries), in neurosurgery where it is important to monitor patients after pituitary gland, hypothalamus and frontal lobe surgery, as well as dermatology when dealing with body dysmporphic disorder, dysmorphobias, prurigo, psoriasis, pemphigus, acne and alopecia. The importance of consultation-liaison psychiatry is clearly seen in other departments such as: urology, especially with dialysis, gastroenterology, alcohol addicts, endocrinology, especially with diabetics who need psychiatric consultation to deal with illness in the best possible way, in neurology because of frequent depressions and acute psychoorganic syndrome from suffered brain stroke and in anesthesiology at the Center for pain management.

Consultation-liaison psychiatry and psychsomatic medicine staff consists of: head of department, head nurse, psychiatrist-doctors (18 all together) all employed at the Department, psychiatry residents, a psychologist and a social worker.

The head of Department Unit for consultation-liaison psychiatry and psychosomatic medicine is in charge of work coordination, organizes work schedule and participates in everyday work. Furthermore, he/she is in charge of professional expertise, cooperates with other Heads of Department, Institutions and Divisions, and within hospital arranges collaboration for providing consultation-liaison service. He works closely with other Heads of Department, specialist doctors and residents within the Unit Departments of consultation- liaison psychiatry. In addition, he/she carries out scientific work and finds new possibilities within Department Units, ensures computerization for the Department's register for obtaining valuable information on psychiatric consultation and in cooperation with head nurse oversees work within the field of consultation-liaison psychiatry.

Head nurse of consultation-liaison psychiatry manages medical documentation, organizes work schedule in agreement with the Head nurse of the Department and other head nurses within Department, coordinates with Head nurses of other Departments, Institutes and Units where diagnostic and therapeutic procedures are carried out, coordinates with Department doctors who perform diagnostic and therapeutic procedures at Clinics, Institutes, Day Units, Outpatient Units and Semi -clinics. Furthermore, she enters information in computer system which is Unit Department's basic register framework and serves the purpose of extracting valuable data on hospital needs for psychiatric consultation (data base for consultationliaison services is formed), is in charge of nurses education from non-psychiatric medicine departments about the healing process of a psychiatric patient while being treated for physical illness and finally offers help in providing psychiatric nurse diagnoses with non-psychiatric patients and informs them patients how to cope emotionally with their illness.

Consultation-liaison psychiatry work is organized through 24 hour service. The service can be given as an emergency psychiatric consultation which has to be carried out within 15 minutes, and this will be specifically indicated on a medical referral for psychiatric consultation, following by a consultation which has to be carried out in 24 hours, and then followed by a consultation during reg- 
ular working hours of a psychiatrist. There is also a possibility of carrying out psychiatric rounds in non-psychiatric departments if the need occurs, which would be followed by a couple of patients' follow ups in order to continuously monitor their progress or possible deterioration.

That kind of continued work organization of consultation-liaison psychiatry service requires the participation of all psychiatrists who run their "own" departments where they spend their regular working hours, following by a psychiatrist who is on call and who is a "senior service", head nurse in charge of administration, register, data base and cooperation with nurses who work in "somatic" departments, psychologist who manages psychotherapy and does patients' psychological testing based on which he can determine the degree and type of mental disorder, personality structure and defense mechanisms and abilities to face and cope with problems. Social worker is also involved for the purpose of resolving potential patient's social issues and problems, contacting patient's family, communicating with a patient and their family about problems and the way of resolving them and achieving the best possible solution.

\section{Research work}

In order to show as much as realistically and vividly as possible the work and efficiency of Consultation- liaison psychiatry in "Sestre milosrdnice" at the Department of Psychiatry, the paper presents the total number of psychiatric consultations in the last 10 years (from 1999 to 2008). The table clearly indicates the growing need for psychiatric consultations. In the last 10 years there has been a significant number of psychiatric services although there is an obvious increase in the number of psychiatric consultations in the period of last 3 years (from 2006 to 2008). Therefore, given the obtained data, it is reasonable to expect even more growing need for psychiatric consultation which strongly indicates the importance of development and practical usage of Consultation- liaison psychiatry and psychosomatic medicine.

\begin{tabular}{|c|c|}
\hline $\begin{array}{l}\text { The year of } \\
\text { psychiatric } \\
\text { consultation }\end{array}$ & $\begin{array}{l}\text { The number } \\
\text { of psychiatric } \\
\text { consultations }\end{array}$ \\
\hline 1999 & 697 \\
\hline 2000 & 706 \\
\hline 2001 & 748 \\
\hline 2002 & 751 \\
\hline 2003 & 767 \\
\hline 2004 & 784 \\
\hline 2005 & 701 \\
\hline 2006 & 816 \\
\hline 2007 & 1078 \\
\hline 2008 & 1094 \\
\hline 2009 & 1157 \\
\hline 2010 & 1293 \\
\hline 2011 & 1435 \\
\hline 2012 & 1203 \\
\hline 2013 & 1192 \\
\hline 2014 & 1070 \\
\hline 2015 & 1002 \\
\hline 2016 & 1253 \\
\hline
\end{tabular}

Consultation- liaison psychiatry and psychosomatic medicine acts as an intermediary between the Department of Psychiatry including all its psychiatry departments (Department of Clinical and Social Psychiatry, 
Alcoholism department, Addictions department, Close Supervision of Psychiatry- Intensive Care, Day Unit and Outpatient Unit) and with the rest of Departments within Sestre milosrdnice University Hospital. In order to allow the continuous and steady work of Consultation- liaison psychiatry and to satisfy all the standards and needs through holistic approach regarding patient's care, Consultation- liaison psychiatry apart from consultation, also provides education in this respect.

For the cooperation of Consultation- liaison psychiatry and psychosomatic medicine with other Departments within Sestre milosrdnice to be more successful, it is crucial to educate non-psychiatrist doctors about the mental illness and patients and that form of education is provided by psychiatrists during their stay in "somatic" departments. Apart from psychiatrists, during psychiatric consultation referring doctors should be present and through conversation find the reason for the consultation and what to expect from the patient's condition. After performing a structured conversation with a patient, the psychiatrist will inform the supervising/referring doctor of the current mental state and ask for a feedback from a non-psychiatrist doctor.

Medical nurses who work in non-psychiatry departments are also required to receive suitable education and to adopt adequate approach for a psychiatric patient and health care. That form of education is performed by a well- qualified and trained medical nurse through various organized lectures and seminars at Sestre milosrdnice with the intention of familiarizing medical nurses from nonpsychiatric departments with necessary care and specific needs of psychiatry patients. The important part of education focuses on destigmatization and breaking down nurses' prejudices who work in non-psychiatry departments regarding psychiatric patients and with the final aim of accepting them as equal patents who suffer from different "somatic" disorders. Psychologist's task is to explain the importance of health psychology in Consultation- liaison psychiatry and to describe possible psychological reactions to physical disorder, at the same time not forgetting to point out the advances in bio-psycho-social approach.

The Department of Consultation-liaison psychiatry and the Department of Psychiatry, as part of their education, are planning to organize professional seminars from the field of consultation-liaison psychiatry and clinical psychiatry. Seminars will be organized according to the model of Zagreb Alcohology School which is already active within the Department. The program would generally encompass and deal with various topics: cardiology and psychiatry, psychodermatology, psychopharmacs in Consultation-liaison psychiatry, suicidal behavior, acute psychoorganic syndrome and Consultation-liaison psychiatry, depressive disorders, alcohol and illegal substances addiction in Consultation-liaison psychiatry and psychosomatic medicine, psychotic disorders and anxiety and somatoform disorders in consultation- liaison psychiatry. The plan is to organize education for psychiatrists in regional hospitals (county and clinical) who would afterwards organize and set up Consultation-Liaison services.

Consultation-liaison psychiatry carries out various scientific research, adapted and organized upon the principle of applicability in everyday professional life, which means that all the information obtained from the register and computer data base system in everyday work represent the groundwork which serves to get information on practical functioning 
of Consultation-liaison psychiatry. Scientific work includes epidemiological research and explores in what way psychoneuroendocrinoligal and inflammatory processes lead to schizophrenia and mood disorders. Psychoneuroimmunology and inflammatory indicators of somatoform disorders are tested and it is shown how psychoendocrinological and psychimmunolgy indicators cause different somatic illnesses such as: diabetes, malignant diseases and various skin disorders [16].

In addition, scientific works demonstrate specific influence of psychopharmacs on physical health.

In the next table we can see the prevalence of psychiatric consultation at the Department of Psychiatry regarding the type of mental disorder. It is evident from the chart that the biggest percentage of psychiatric consultation was given to patients with psychoorganic syndrome and disorder (33\%), anxiety disorders $(12 \%)$, patients with alcohol addiction and depression (11\%), mental disorders (8\%) and addictive disorders (7\%). Smaller percentage is present in patients with dementia, stress related reactions and patients who clearly show symptoms of suicidal behavior ( around 4\%), following by personality disorder $(3 \%)$, dissociative disorder, polytoxicomania, adjustment disorder, somatoform disorders, sleeping disorder and conditions excluding mental disorders (each $2 \%$ ), and finally with patients suffering from other disorders such as bipolar, obsessive-compulsive disorder, eating disorder and intellectual disability (each 1\%).

Next table shows the prevalence of psychiatric consultation regarding various departments in Sestre milosrdnice which provided consultation. Chart clearly indicates that the biggest percentage of psychiatric consultation is provided in the Department of Internal Medicine (38\%), Department of Neurology $(19 \%)$, Department of Surgery $(13 \%)$, Department of Gynecology and Obstetrics (8\%) and at the Department for Skin and Sexually Transmitted Diseases (7\%). Smaller percentage refers to the rest of the Departments such as: Department of Neurosurgery, Department of Urology, Department of Otorhinolaryngology, Department of Pediatrics, ( around 3\%), followed by: Department of Ophthalmology, Division of Anesthesiology, Department of Pulmonary Medicine, Department of Oncology, Department of Rheumatology (around 2\% ) and Department of Physical Medicine and Rehabilitation $(1 \%)$.

\section{Administration}

Each Department within Sestre milosrdnice has its own special referrals for psychiatric consultation written in duplicate (the original stays at the Department which sought psychiatric consultation and the copy at the Department of Consultation-liaison psychiatry). The medical referral consists of four parts: first part - general information, second part-patients' information, third part- psychiatric information on the patient and reasons for psychiatric consultation according to the opinion of a non-psychiatry doctor specialist and fourth part filled out by a consultationliaison staff and consultation psychiatrist.

The first part contains the name of the clinic and the department, infirmary code, code and a telephone number of a doctor who seeks psychiatric consultation.

Second part contains information on a patient who is in need of psychiatric consultation and are as follows: identification number, name and surname, age, sex, patient's condition (inpatient or outpatient). 
Third part deals with clinical diagnosis of physical disorder as well as psychiatric diagnosis or with a symptom description and visible signs in a patient who is need of a psychiatrist consultation. It is important to point out whether psychiatric consultation is urgent or it can be done within 24 hours during regular working hours, not forgetting to mention if this is the first or repeat consultation, and to inform a patient about a psychiatrist consultation. It is significant to note whether patient's mental state is a consequence of physical illness, psychological reaction to illness, treatment or hospitalization or whether it is primary mental disorder. Furthermore, it should be clear what to expect from consultation (psychopharmacotherapy, psychotherapy, conversation with a family, transfer to psychiatry, or a conversation with a medical team who supervises the patient). If necessary, some remarks about the patient can be mentioned. It is required to put a date on a referral along with a signature of a referring doctor.

The fourth part of the referral has a code of consultation-liaison psychiatry and psychosomatic medicine, protocol number and a code of a psychiatrist who will perform the consultation and write a medical report after examining the patient. Psychiatric medical report is half structured containing short anamnesis, description of mental status, diagnosis (MKB 10), therapy prescribed by a psychiatrist and possible recommendation for patient's follow up. It is obligatory to put a date of the consultation accompanied with the signature of a psychiatrist who did psychiatrist consultation.

Consultation--liaison psychiatry and psychosomatic medicine at Sestre milosrdnice, Croatia achieved international cooperation with the Department of Psychiatry of University of Modena, the Department of Psychiatry of the University of Trieste and with EACLPP members.

\section{Conclusion}

In this paper the primary purpose is to stress the importance of complete, holistic approach in providing care for each patient (accepting the patient's uniqueness and individuality) both in diagnostics and in treatment of non-psychiatric patients in accordance with bio-psycho-social approach. The result is the logical connection between consultation-liaison psychiatry and psychosomatic medicine as well as complementary practical interaction of a psychiatrist in relation to mental and physical, together with observing their mutual relationship.

\section{Acknowledgments}

None

\section{Conflict of interest}

None to declare

\section{References}

1. Mandić N. Konzultativno-suradna (liaison) psihijatrija. Zagreb, Croatia: Medicinska naklada; 1995.

2. Buljan D. Konzultativno-suradna psihijatrija. Jastrebarsko, Croatia: Naklada Slap; 2016.

3. Levy NB. Psychosomatic medicine and consultation - liaison psychiatry: past, present and future. Hosp Community Psychiatry. 1989;40:1049-56.

4. Gregurek R. Suradna i konzultativna psihijatrija. Zagreb, Croatia: Školska knjiga; 2006. 
5. Gitlin DF, Levenson JL, Lyketsos CG. Psychosomatic Medicine: A New Psychiatric Subspecialty. Acad Psychiatry. 2004;28:4-11.

6. Lipsitt DR. Consultation-liaison psychiatry and psychosomatic medicine: the company they keep. Psychosom Med. 2001;63:896-909.

7. Glaser J. Važnost neurološko-psihijatrijskih odjela u organizaciji psihijatrijske službe zdravstvene službe uopće. Narodno zdravlje. 1946;3:40.

8. Hudolin V. Klinička bolnica „Dr. Mladen Stojanović“ Zagreb, 1945-1985. Zagreb, Croatia: Klinička bolnica „Dr. Mladen Stojanovićc; 1985.

9. Čačković M. Slučaj traumatske psihoze izliječene trepanacijom. Liječnički vjesnik. 1897;19:360.

10. Julius D. O uređenju psihijatrijsko - neurološke službe u Hrvatskoj. Liječnički vjesnik. 1946;22-6.

11. Sharrock J, Happell B. The psychiatric consultation-liaison nurse: Thriving in a general hospital setting. Int J Mental Health Nurs. 2002;11:24-33.
12. American Nurses Association. Magnet recognition program: Recognizing excellence in nursing services. Silver Springs, USA: American Nurses Credentialing Center; 2005.

13. Cross W, Moore A. Psychiatric consultation liaison nurse (P.C.L.N.) project report. Clayton, Australia: Southern Health Nursing Education and Research; 2006.

14. Ragaisis KM. The psychiatric consultation-liaison nurse and medical family therapy. Clin Nurse Spec. 1996;10:50-6.

15. Kurlowicz LH. Psychiatric consultation-liaison nursing. In: A.W. Burgess (Ed.) Advanced practice psychiatric nursing. Stamford, USA: Appleton \& Lange: 1998.

16. Vuk Pisk S, Mihanović M, Filipčić I, Bogović A, Ruljančić N. The impact of obesity on suicidality among female patients suffering from bipolar affective disorder: the indirect role of body dissatisfaction. Alcoholism and Psychiatry Research. 2017;53:5-13

\section{Konzultativno-suradna psihijatrija i psihosomatska medicina Model kliničkog bolničkog centra Sestre milosrdnice}

Sažetak - Kroz ovaj rad prikazujemo aktivno djelovanje Odjela konzultativno-suradne psihijatrije i psihosomatske medicine kao prvog i trenutno jedinog formalno osnovanog odjela takve vrste u Republici Hrvatskoj. Aktivnosti iz područja Konzultativno-suradne psihijatrije se u Kliničkoj bolnici "Sestre milosrdnice" odvijaju praktički od samog osnutka psihijatrije u bolnici, već desetljećima. Također Odjel kao zasebna organizacijska jedinica postoji unazad šest godina. U radu Odjela za konzultativno-suradnu psihijatriju i psihosomatsku medicinu istaknuli bi važnost konzultacije i suradnje između specijalista tjelesne medicine i psihijatara, te naglašavamo značajnu ulogu psihosomatskog aspekta u tjelesnoj bolesti. Također težište rada je isticanje važnosti uloge psihijatra u otkrivanju, dijagnostici i liječenju tjelesnih bolesnika s psihijatrijskim komplikacijama, a ostatku medicinskog tima ukazati da je svaki bolesnik osoba sa biološkom, psihološkom i socijalnom dimenzijom ili drugim riječima njegovanje holističkog, biopsihosocijalnog pristupa svakom bolesniku bio on samo tjelesni bolesnik ili i bolesnik s psihijatrijskim tegobama.

Ključne riječi: konzultativno-suradna psihijatrija, psihosomatska medicina, bolnica, organizacija psihijatrijske službe, psihijatrijski poremećaji u tjelesnih bolesnika 